\section{Physiological Changes Associated with Performance of Kentucky Bluegrass Cultivars during Summer Stress}

\author{
Pedro Perdomo, James A. Murphy, and Gerald A. Berkowitz \\ Department of Plant Science, P.O. Box 231, New Jersey Agricultural Experiment \\ Station, New Brunswick, NJ 08903-0231
}

Additional index words. Poa pratensis, leaf water potential, stomatal resistance, infrared thermometer, leaf : air temperature differential, osmotic potential

\begin{abstract}
Understanding the factors influencing the performance of Kentucky bluegrass (Poa pratensis $\mathbf{L}$.) cultivars under summer stress is necessary for developing criteria for identifying resistant germplasm. The objectives of this study were to evaluate two Kentucky bluegrass cultivars for leaf water $\left(\psi_{1}\right)$ and osmotic potential $\left(\psi_{\pi}\right)$, stomatal resistance $\left(\mathbf{R}_{\mathrm{s}}\right)$, leaf : air temperature differential $(\Delta T)$ and determine the relationship of these parameters to drought and heat tolerance. Stress-resistant ('Midnight') and susceptible ('Nugget') cultivars were evaluated in a field study during 1993 and 1994 under moisture-limiting conditions. Leaf water potential for 'Nugget' was higher than for 'Midnight' in 1993 and similar in 1994. 'Midnight' had lower $\psi_{\pi}$ than 'Nugget' during the evaluation period in 1994. 'Midnight' maintained more open stomata (lower $R_{s}$ ) and lower $\Delta T$ than 'Nugget' at the end of the dry down period when 'Nugget' was showing visual signs of stress. 'Midnight' and 'Nugget' had similar root weight at the 0 - to 45-cm depth zone in 1994. Lower basal osmotic potential (i.e., higher solute concentration) may be the physiological mechanism allowing larger stomatal aperture in 'Midnight'. Greater transpirational cooling in 'Midnight' relative to 'Nugget' was correlated with higher turf quality for 'Midnight'.
\end{abstract}

Kentucky bluegrass is a widely used turfgrass in all but the warmest parts of the United States (Bashaw and Funk, 1987; Schery, 1976). Persistent cultivars of Kentucky bluegrass are needed for low-maintenance sites, including lawns, parks, and roadsides. With increasing environmental scrutiny being placed on water allocation and use, research has focused on producing high-quality turf that helps conserve water (Beard et al., 1992; Feldhake et al., 1983). Biran et al. (1981) found that reduced irrigation frequency decreased water consumption and growth rate of several turfgrasses; however, most of the grasses exhibited wilt stress. Leaf wilt is undesirable on highly trafficked turfs because plants are more susceptible to damage and have reduced recuperative capacity resulting in decreased aesthetic and functional quality of the turf (Carrow and Petrovic, 1992).

Many years of field observations have identified Kentucky bluegrass cultivars and selections that maintain growth under nonirrigated

Received for publication 16 Jan. 1996. Accepted for publication 27 July 1996 . Research supported by the Center for Turfgrass Science, New Jersey Agricultural Experiment Station, Peter Selmer Loft Scholarship Fund, and the New Jersey Turfgrass Association. Publication No. E-122-64-5-96. We thank C. Reed Funk and Michael D. Richardson for their contributions to this project. Mention of a proprietary product does not imply its approval to the exclusion of other products that may also be suitable. The cost of publishing this paper was defrayed in part by the payment of page charges. Under postal regulations, this paper therefore must be hereby marked advertisement solely to indicate this fact. conditions for a moderate period of time, but the mechanisms for enhanced performance are not well understood. It is important to identify characteristics of plants that influence turf performance during summer stress periods. Although many plants are able to persist under drought stress, their mechanisms of (1992) proposed that the maintenance of high water potential through decreased transpiration is "particularly significant for turfgrass in that it translates to maximum retention of drought resistance are diverse. Beard et al. stopped in 1993 and 1994. green vegetative canopy." Salaiz et al. (1991) stated that "turfgrasses with decreased evapotranspiration (ET) rates maintain a favorable $\psi_{1}$ by conserving water" and suggested that decreased transpirational water loss may be a desirable trait for turfs grown under limited water availability. This proposed conceptual stress model was developed under wellwatered conditions and, therefore, may be useful as a selection criterion under such conditions. However, the suitability of this model for turfs maintained under water-limiting conditions needs to be determined. The model suggests that decreased transpiration resulting in favorable $\psi_{1}$ may be a physiological basis for the differences in performance of Kentucky bluegrass genotypes under stress.

Osmotic adjustment, the ability of cells to accumulate solutes in response to decreasing plant water potential, can also result in turgor maintenance and drought resistance under conditions of limited moisture (Gunasekera and Berkowitz, 1992; White et al., 1992). Gunasekera and Berkowitz (1992) reported that drought-resistant wheat genotypes (Triticum sp.) maintained more positive turgor potential $\left(\psi_{\mathrm{p}}\right)$ than drought-susceptible genotypes as a result of osmotic adjustment. White et al. (1992) evaluated tall fescue (Festuca arundinacea Schreb.) for turgor maintenance under drought stress and found that plant survival was strongly related to osmotic adjustment.

Soil water depletion, leaf water potential, and stomatal closure can have a direct effect on leaf temperature (Ehrler et al., 1978; Idso et al., 1981). Walker and Hatfield (1983), using an infrared thermometer, found that leaf temperature could be used more readily than diffusion porometry to detect differences between well-watered and drought-stressed kidney bean (Phaseolus vulgaris L.) plants. Leaf temperature has been used to detect stomatal closure (Ehrler et al., 1978; Walker and Hatfield, 1983) and canopy minus air tem-

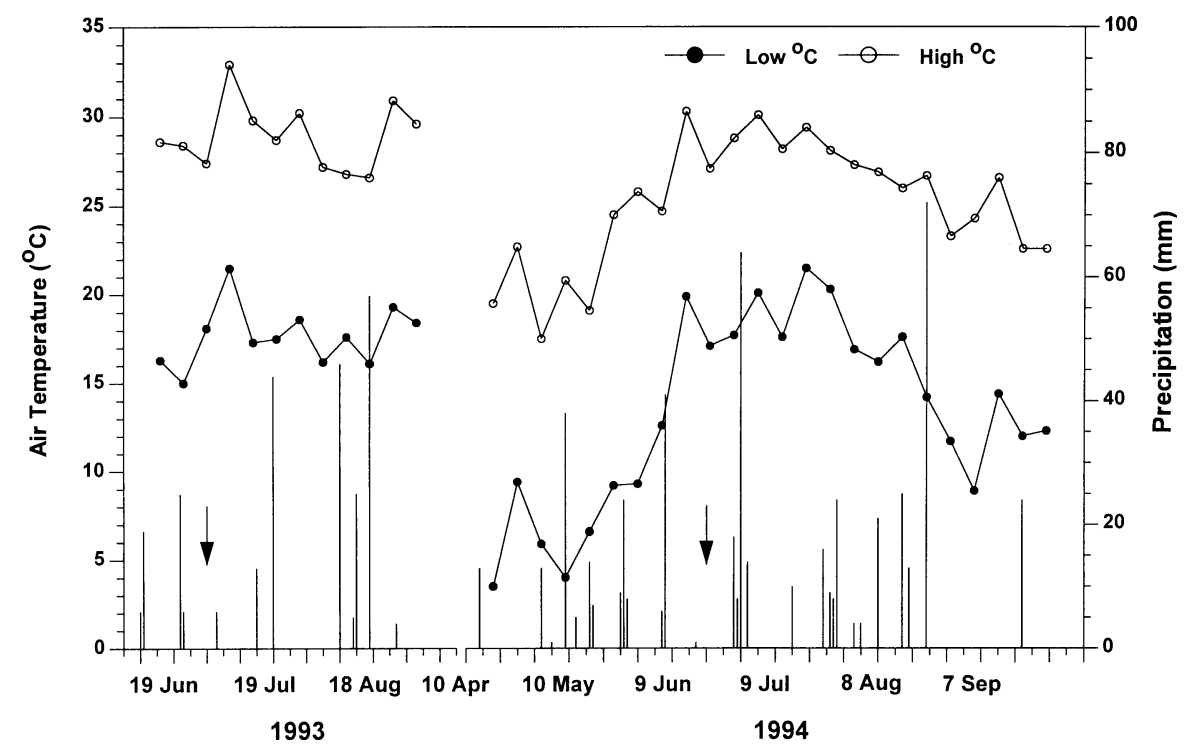

Fig. 1. Weekly mean low and high temperatures and rainfall amounts during the periods of study in 1993 and 1994. Vertical lines are amounts of precipitation. Arrows indicate the dates when irrigation was 
perature $(\Delta \mathrm{T})$ has been used to monitor heat and drought stress in several turfgrass species (Sifers and Beard, 1993; Throssell et al., 1987).

The objectives of this study were to compare changes in $\psi_{1}, \psi_{\pi}, \mathrm{R}_{\mathrm{s}}$, and $\Delta \mathrm{T}$ in two Kentucky bluegrass cultivars during increasing drought stress and to determine the relationship of these parameters to stress-resistant germplasm.

\section{Materials and Methods}

The summer stress resistance of Kentucky bluegrass cultivars was investigated in a field trial established in Sept. 1990 on a Nixon loam soil (fine-loamy, mixed, mesic Typic Hapludult). The design was a randomized complete block with three replications of plots measuring $1.1 \times 1.6 \mathrm{~m}$. Plots were mowed at $3.8 \mathrm{~cm}$ and mowing frequency was based on the growth rate, with as many as three mowings per week during vigorous growth. Soil $\mathrm{pH}$ ranged from 6.4 to 6.5 . Fertilization in 1993 consisted of $12 \mathrm{~N}-1.8 \mathrm{P}-6.6 \mathrm{~K}$ with $\mathrm{N}\left(\mathrm{kg} \cdot \mathrm{ha}^{-1}\right)$ at 30 on 9 Apr. and 17 May, 37 on 2 June, 26 on 20 Sept., and of $10 \mathrm{~N}-4.4 \mathrm{P}-8.3 \mathrm{~K}$ with $\mathrm{N}$ at 30 on 30 Oct. In 1994 , we used only $12 \mathrm{~N}-$ $1.8 \mathrm{P}-6.6 \mathrm{~K}$, with $\mathrm{N}$ at 30 on 16 June, 22 on 2 July, 18 on 6 July, 37 on 22 Sept., and 28 on 25 Oct. Irrigation was applied to prevent drought stress, except during periods of evaluation (water withheld after 28 June 1993 and 20 June 1994). Total rainfall amounts were similar in both years; however, rainfall events were less frequent in 1993 than 1994 (Fig. 1).

Cultivars were selected for evaluation of heat and drought resistance based on previous performance ratings in field trials (Dickson et al., 1992). One stress-resistant ('Midnight') and one susceptible ('Nugget') Kentucky bluegrass cultivar were evaluated from 8 July to 10 Aug. 1993 for $\psi_{1}, \Delta \mathrm{T}$, turf quality, and wilt. The cultivars were evaluated for $\psi_{1}, \psi_{\pi}, \Delta \mathrm{T}, \mathrm{R}_{\mathrm{s}}$, and turf quality from 13 June to 25 July 1994. Turf quality was rated visually three to four times per week on a 1 to 9 scale with $1=$ dormant turf and $9=$ dense, nonstressed turf. Leaf water potential of fully expanded, mature, nonsenescing leaf blades was determined two to three times a week with a model 3005 plant water status console equipped with a model 3019G4-008 sealing grommet (Soil Moisture Equipment Corp., Santa Barbara, Calif.) at solar noon $( \pm 1 \mathrm{~h})$. A moistened paper towel was placed in the pressure chamber to minimize desiccation of leaf blades during measurements. Three and five leaf blades were sampled per plot in 1993 and 1994, respectively. Leaf water potential was determined by pressurizing the chamber with $\mathrm{N}$ gas until plant sap accumulated at the cut end of the leaf (Turner, 1981). Leaf blades were collected at the time that $\psi_{1}$ was measured for determination of $\psi_{\pi}$ in 1994. Five fully expanded, mature, nonsenescing leaf blades were excised, carefully wiped clean and rehydrated at $4{ }^{\circ} \mathrm{C}$ for $24 \mathrm{~h}$. After rehydration, the leaves were blotted dry, wrapped in plastic wrap, immersed in liquid $\mathrm{N}$, and stored at $-15^{\circ} \mathrm{C}$ until $\psi_{\pi}$ was determined. Osmotic potential of the leaves was determined using a thermocouple psy-

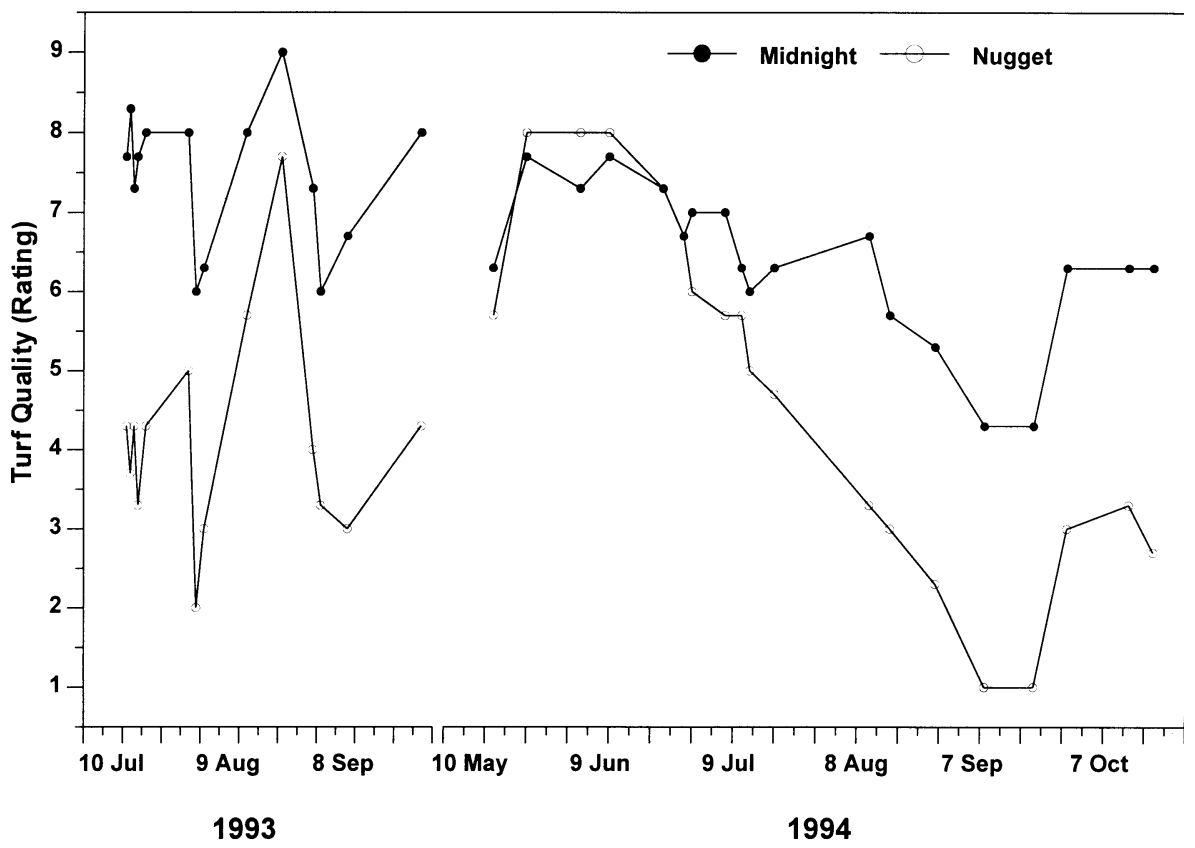

Fig. 2. Turf quality ( $9=$ best quality/no stress) of 'Midnight' and 'Nugget' Kentucky bluegrass in 1993 and 1994. Mean turf quality ratings for 'Midnight' and 'Nugget' were $7.5 \pm 0.2$ and $4.1 \pm 0.2$, respectively, in 1993. Data were pooled into low (12 May to 27 June) and moderate (29 June to 19 Oct.) stress for paired $t$ tests. 'Midnight' had a mean rating of $7.2 \pm 0.2$ and $6.0 \pm 0.2$ during periods of low and moderate stress, respectively, in 1994. 'Nugget' had a mean rating of $7.3 \pm 0.2$ and $3.6 \pm 0.3$ during periods of low and moderate stress, respectively, in 1994.
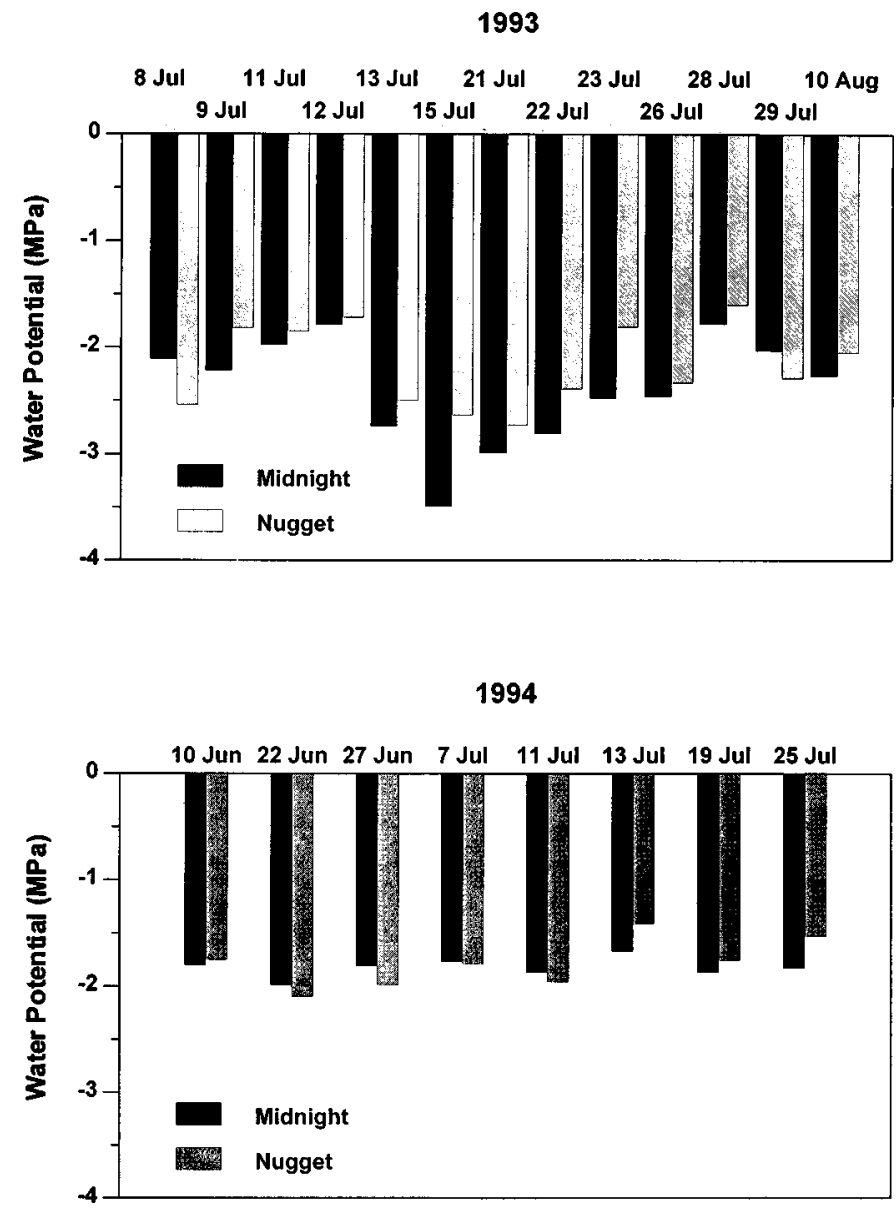

Fig. 3. Leaf water potential $\left(\psi_{1}\right)$ of 'Midnight' and 'Nugget' Kentucky bluegrass in 1993 and 1994 . The pooled means $\psi_{1}$ for 'Midnight' and 'Nugget' were $-2.40 \pm 0.09$ and $-2.17 \pm 0.07 \mathrm{MPa}$, respectively, in 1993. 'Midnight' and 'Nugget' had a pooled mean $\psi_{1}$ of $-1.87 \pm 0.08$ and $-1.94 \pm 0.09$, respectively, from 10 to 27 June 1994. 'Midnight' and 'Nugget' had a pooled mean $\psi_{1}$ of $-1.80 \pm 0.04$ and $-1.69 \pm$ 0.07 , respectively, from 7 to 25 July 1994 . 
chrometer operated in the dewpoint mode (Sen Gupta and Berkowitz, 1987; Turner, 1981).

A model AG42 (Telatemp, Fullerton, Calif.) infrared thermometer was used to measure $\Delta \mathrm{T}$ for 'Midnight' and 'Nugget' three to five times a week from 9 July to 11 Aug. 1993 and from 23 Apr. to 12 Sept. 1994. Emissivity, the ratio of radiation emitted by an object to that of a blackbody at a given temperature, was set to 0.95 , as suggested by Tanner (1963). Measurements were made on sunny days at solar noon $( \pm 0.5 \mathrm{~h})$ when temperatures approached the daily maximum (Croft et al., 1993). The infrared thermometer was held $0.9 \mathrm{~m}$ above the turf and three readings per plot were taken in 1993. Twelve readings per plot were made in 1994.

Stomatal resistance $\left(\mathrm{R}_{\mathrm{s}}\right)$ was measured using an ADC infrared gas analyzer (Akofi, Buffalo, N.Y.) on four dates from 12 to 24 July 1994 (Pier and Berkowitz, 1987). Three mature, nonsenescing leaves per plot were enclosed in the leaf chamber at one time for measurement of $R_{s}$.

The genotypes were evaluated for root mass using a $2.54-\mathrm{cm}$-diameter soil probe to collect three 45 -cm-long samples per plot on 24 Aug. 1994. Thatch was removed from the samples and the roots were washed free of soil using a hydropneumatic elutriation system (Smucker et al., 1982).

Data analysis. Paired $t$ tests (Steel and Torrie, 1980) were performed on all data for $\psi_{1}, \Delta \mathrm{T}$, turf quality, and wilt pooled over the entire measurement period in 1993. Turf quality, $\psi_{\mathrm{l}}, \psi_{\pi}, \Delta \mathrm{T}$, and $\mathrm{R}_{\mathrm{s}}$ data were pooled into two stress groups (low and moderate) based on turf quality, and paired $t$ tests were performed in 1994. Cultivars exhibited good turf quality and minimal stress symptoms during the low stress dates, whereas turf quality decreased sharply during the moderate stress dates in 1994.

\section{Results and Discussion}

Turf quality, evaluated from 10 July to 24 Sept. in 1993 (Fig. 2), indicated that 'Midnight' maintained acceptable turf quality throughout the evaluation period, whereas 'Nugget' fell below acceptable (rating = 5) turf quality during most of this period in 1993 . Turf quality measurements recorded from 12 May to 19 Oct. 1994 (Fig. 1) indicated that 'Midnight' and 'Nugget' had similar turf quality between 12 May and 27 June, but 'Midnight' maintained higher turf quality throughout the remainder of the evaluation period. 'Nugget' fell below acceptable turf quality by 13 July, whereas 'Midnight' did not fall that low until 8 Sept.

Beard (1989) and Salaiz et al. (1991) proposed that maintenance of higher (i.e., less negative) $\psi_{1}$ would be associated with better turf performance during drought stress periods. Based on this proposal, we expected that 'Midnight' would have higher $\psi_{1}$ than 'Nugget'. Conversely, 'Midnight' had lower $\psi_{1}$ than 'Nugget' in 1993, with differences being greatest during the peak stress period of 13 to 21 July (Fig. 3). Additionally, 'Midnight' also

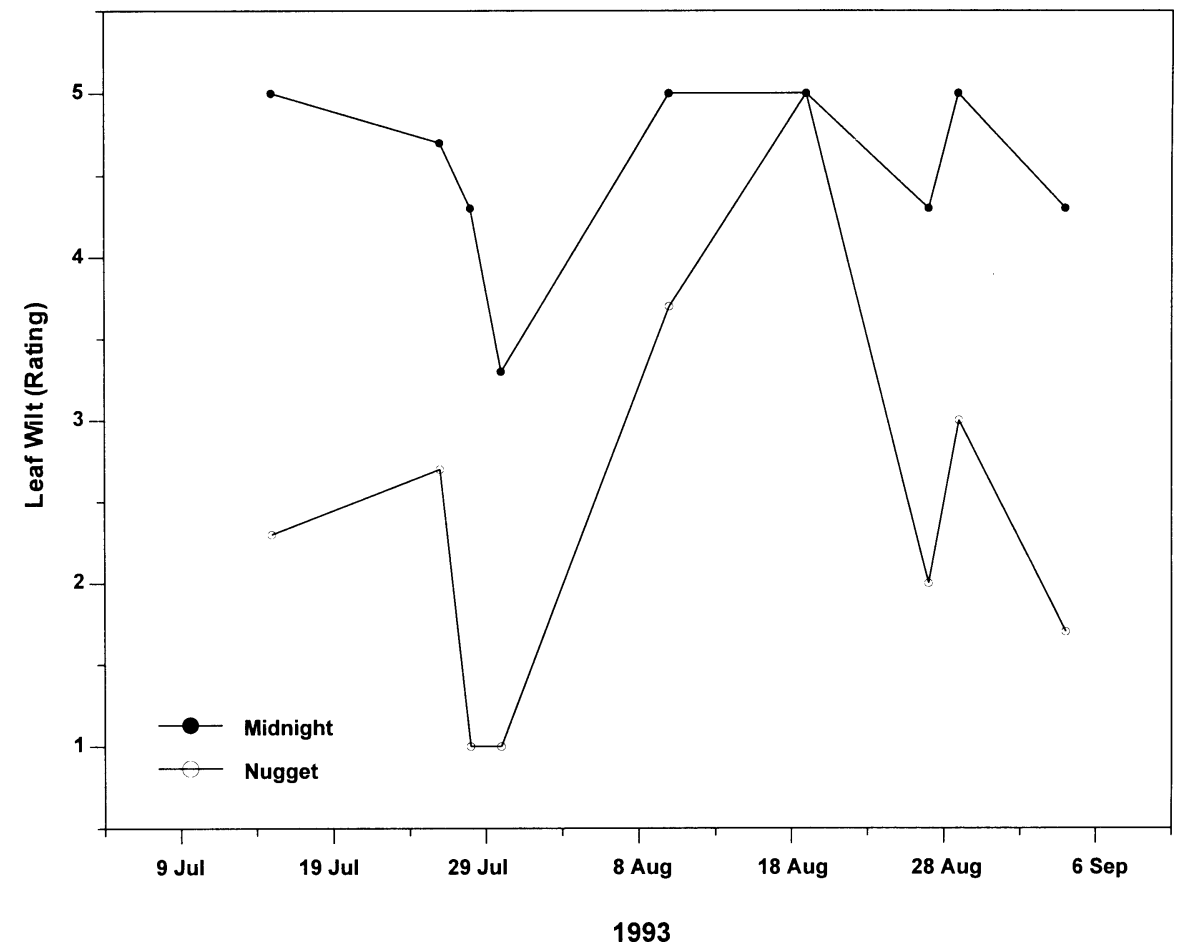

Fig. 4. Leaf wilt ratings $(5=$ no wilt) of Kentucky bluegrass cultivars Midnight and Nugget in 1993. The pooled mean wilt ratings for 'Midnight' and 'Nugget' were $4.6 \pm 0.1$ and $2.5 \pm 0.3$, respectively, from 15 July to 5 Sept.

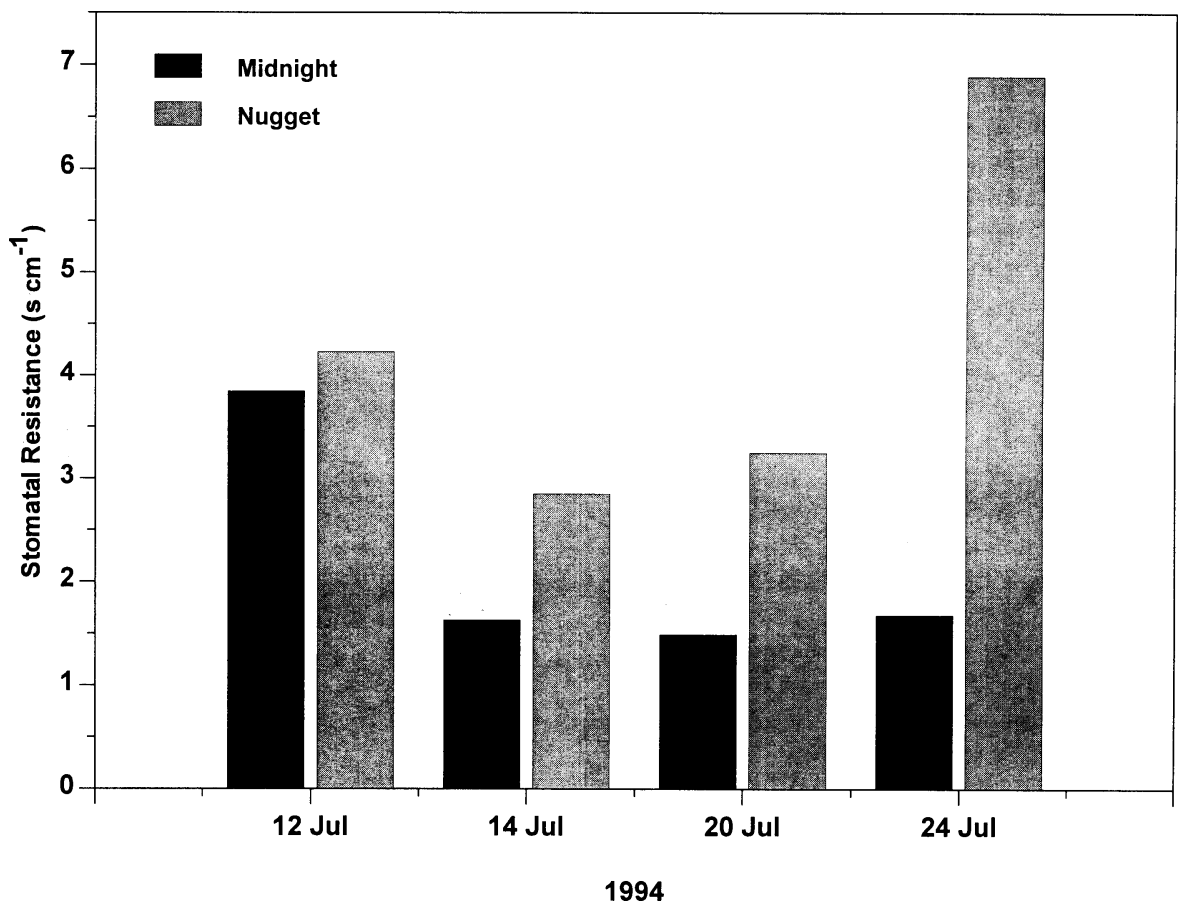

Fig. 5. Stomatal resistance $\left(\mathrm{R}_{\mathrm{s}}\right)$ of 'Midnight' and 'Nugget' Kentucky bluegrass in 1994. The pooled mean $\mathrm{R}_{\mathrm{s}}$ for 'Midnight' and 'Nugget' were $2.21 \pm 0.42$ and $4.44 \pm 0.69$, respectively, from 12 to 24 July.

exhibited less leaf wilt than 'Nugget' on all but 1 day in 1993 (Fig. 4). Leaf water potential was similar for 'Midnight' and 'Nugget' in 1994. Similarity in $\psi_{1}$ along with nonsignificant differences in rooting (data not shown) suggest that differential water uptake was not the reason for higher quality in 'Midnight' than 'Nugget'. Leaf wilt has been shown to be associated with increased $R_{\mathrm{s}}$ and loss of tur- gor. Carroll and Petrovic (1991) suggested that $R_{\mathrm{s}}$ should be evaluated in terms of turgor potential $\left(\psi_{\mathrm{p}}\right)$ rather than $\psi_{1}$ for Kentucky bluegrass because of the stronger association of $\mathrm{R}_{\mathrm{s}}$ with $\psi_{\mathrm{p}}$.

Stomatal resistance was lower for 'Midnight' than 'Nugget' on 20 and 24 July (Fig. 5). 'Midnight' maintained $\mathrm{R}_{\mathrm{s}}$ below $2 \mathrm{~s} \cdot \mathrm{cm}^{-1}$ from 14 through 24 July, whereas 'Nugget' had $R_{s}$ 
above $2 \mathrm{~s} \cdot \mathrm{cm}^{-1}$ on all dates and reached a high of $6.9 \mathrm{~s} \cdot \mathrm{cm}^{-1}$ on 24 July. It should be noted that 'Midnight' maintained lower $\mathrm{R}_{\mathrm{s}}$ than 'Nugget' during peak stress (Figs. 1 and 4) despite exhibiting similar $\psi_{1}$ during this period (Fig. 3 ). These findings do not fit the previously discussed model that associated decreased transpiration with higher turf quality. In our study, the maintenance of low $R_{s}$ was associated with higher turf quality for 'Midnight' compared to 'Nugget' in 1994.

Increased $\mathrm{R}_{\mathrm{s}}$ should decrease transpiration and transpirational cooling, and subsequently increase $\Delta \mathrm{T}$. 'Nugget' had higher $\Delta \mathrm{T}$ than 'Midnight' on all but the two dates in 1993 when the $\Delta \mathrm{T}$ was low, with the greatest difference being $4.9^{\circ} \mathrm{C}$ on 30 July (Fig. 6). The $\Delta \mathrm{T}$ was similar for the two cultivars between 23 May and 22 June 1994 when stress was low. 'Midnight' had lower $\Delta \mathrm{T}$ than 'Nugget' throughout the remainder of the study in 1994 , with the greatest difference in $\Delta \mathrm{T}$ being $3.4^{\circ} \mathrm{C}$ on 9 Sept. 1994. $\Delta \mathrm{T}$ were not large; however, the fact that differences were significant throughout the stress periods of both test years suggest that there were real physiological differences. These data also suggest that $\Delta \mathrm{T}$ is a more reliable physiological measure of summer stress in Kentucky bluegrass than $\psi_{1}$. Our findings indicate that better turf performance is associated with maintenance of more open stomata allowing for transpirational cooling of leaves under conditions of decreasing $\psi_{1}$.

White et al. (1992) reported that greater basal solute concentration (lower $\psi_{\mathrm{p}}$ ) and osmotic adjustment were primary mechanisms for positive turgor maintenance and drought tolerance in tall fescue (Festuca arundinacea Schreb.). Although limited, our data for $\psi_{\pi}$ support the conclusions of White et al. (1992). 'Midnight' $(-1.86 \mathrm{MPa} \pm 0.03)$ had a significantly $(P \leq 0.05)$ lower $\psi_{\pi}$ than 'Nugget' $(-1.69 \mathrm{MPa} \pm 0.03)$ during the low stress period in 1994. Similarly, $\psi_{\pi}$ was lower $(P \leq$ $0.10)$ for 'Midnight' $(-1.97 \mathrm{MPa} \pm 0.02)$ than 'Nugget' $(-1.86 \mathrm{MPa} \pm 0.02)$ during the moderate stress period in 1994. Thus, lower basal $\psi_{\pi}$ along with osmotic adjustment could be the physiological basis for maintenance of positive turgor and greater stomatal aperture in 'Midnight', resulting in lower $\Delta \mathrm{T}$ for 'Midnight' compared to 'Nugget'.

\section{Conclusion}

Results of this research do not fit the model proposed by Salaiz (1991) and Beard (1992) for drought stress resistance in turfgrasses. Although the previously discussed model is useful in selecting water-conserving (low ET) grasses, it was developed under predominantly well-watered conditions and may be less appropriate for selecting grasses that are resistant to prolonged periods of low soil water availability. Our research was conducted under conditions of limited water availability (no supplemental irrigation) and was intended to select drought-resistant Kentucky bluegrass genotypes that can be used for locations such as roadsides, parks, or medium- to low-maintenance lawns. Drought-resistant

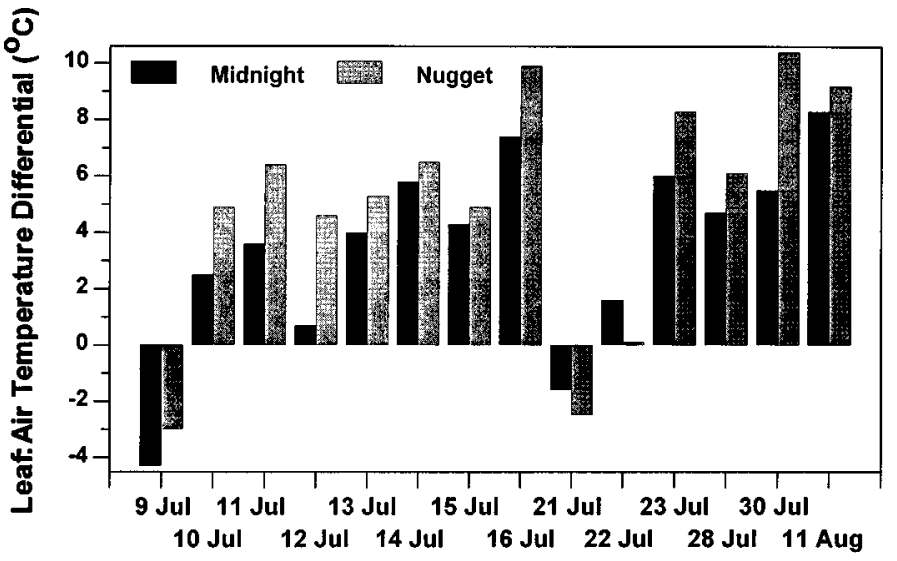

1993

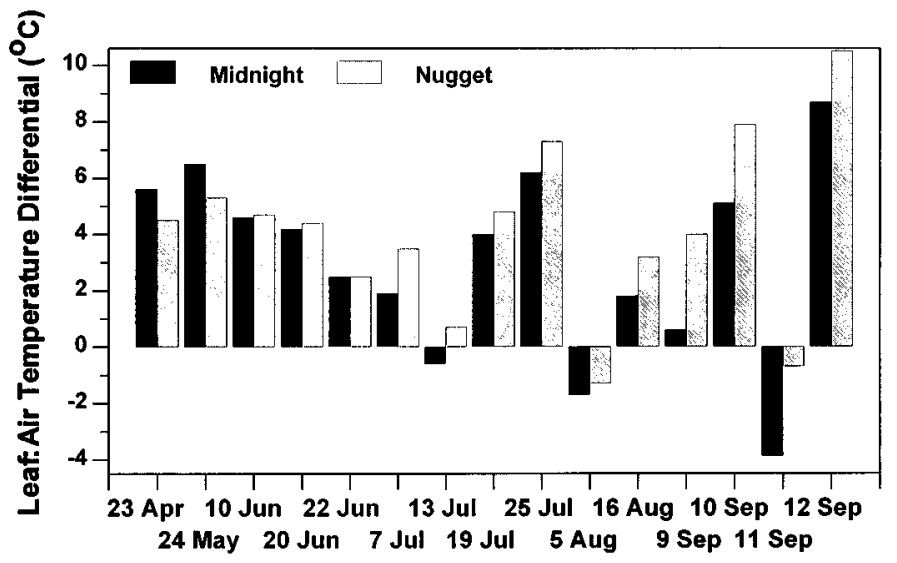

1994

Fig. 6. Leaf : air temperature differential $(\Delta \mathrm{T})$ of 'Midnight' and 'Nugget' Kentucky bluegrass in 1993 and 1994. The pooled mean $\Delta \mathrm{T}$ values for 'Midnight' and 'Nugget' were $3.5 \pm 0.6$ and $5.0 \pm 0.7^{\circ} \mathrm{C}$, respectively, in 1993. 'Midnight' and 'Nugget' had a pooled mean $\Delta \mathrm{T}$ of $4.7 \pm 0.5$ and $4.3 \pm 0.3{ }^{\circ} \mathrm{C}$, respectively, from 23 Apr. to 22 June 1994. 'Midnight' and 'Nugget' had a pooled mean $\Delta \mathrm{T}$ of $2.2 \pm 0.7$ and $4.0 \pm 0.7^{\circ} \mathrm{C}$, respectively, from 7 July to 12 Sept. 1994.

genotypes may not exhibit water-conserving characteristics (low ET) under well-watered or minimal stress conditions, but may be able to maintain a functional, green canopy during drought periods of moderate duration. Droughtresistant genotypes may maintain positive turgor by either osmotic adjustment or more extensive rooting. However, osmotic adjustment seems more likely, because 'Midnight' and 'Nugget' roots weighed similar amounts on 13 Aug, 1994 (data not shown).

Low $\psi_{1}$ may not be injurious to some Kentucky bluegrass genotypes if positive $\psi_{\mathrm{p}}$ and stomatal aperture can be maintained through osmotic adjustment. This suggestion is supported by Pier and Berkowitz (1987) and Sen Gupta and Berkowitz (1987) who concluded that physiological responses (osmotic adjustment) to decreasing $\psi_{1}$ protected against some deleterious effects of drought stress. Larger stomatal aperture, in turn, leads to more transpirational cooling and reduces detrimental heating. Larger stomatal aperture is also needed to maintain $\mathrm{CO}_{2}$ diffusion into leaves, an important component of photosynthetic carbon fixation, and subsequently plant growth
(Sharp and Boyer, 1986). Howard and Watschke (1991) reported that high-temperaturetolerant Kentucky bluegrass cultivars had higher net photosynthetic rates than 'Nugget' when grown at $30^{\circ} \mathrm{C}$. Further evaluation of other Kentucky bluegrass genotypes is needed to determine how broadly these responses apply.

\section{Literature Cited}

Bashaw, E.C. and C.R. Funk. 1987. Apomictic grasses, p. 41-82. In: W.R. Fehr (ed.). Principles of cultivar development. vol. 2. Macmillan, New York.

Beard, J.B. 1989. Turfgrass drought stress: Drought resistance components, physiological mechanisms, and species-genotype diversity, p. 2328. In: H. Takatoh (ed.). The 6th Intl. Turf. Res. Conf., Tokyo, 31 July-5 Aug. 1989.

Beard, J.B., R.L. Green, and S.I. Sifers. 1992. Evapotranspiration and leaf extension rates of 24 well-watered, turf-type Cynodon genotypes. HortScience 27:986-988.

Biran, I., B. Bravado, I. Bushkin-Harav, and E. Rawitz. 1981. Water consumption and growth rate of 11 turfgrasses as affected by mowing height, irrigation frequency, and soil moisture. Agron. J. 73:85-90. 
Carroll, M.J. and A.M. Petrovic. 1991. Nitrogen, potassium, and irrigation effects on water relations of Kentucky bluegrass leaves. Crop Sci. 31:449-453.

Carrow, R.N. and A.M. Petrovic. 1992. Effects of traffic on turfgrass, p. 285-330. In: D.V. Waddington, R.N. Carrow, and R.C. Shearman (ed.). Turfgrass. Amer. Soc. Agron., Crop Sci. Soc. Amer., Soil Sci. Soc. Amer., Madison, Wis.

Croft, P.J., M.D. Shulman, and R. Avissar. 1993. Cranberry stomatal conductivity. HortScience 28:1114-1116.

Dickson, W.K., R.F. Bara, D.A. Smith, S. Sun, and B.B. Clarke. 1992. Performance of Kentucky bluegrass cultivars and selections in New Jersey turf trials. In: P. Ballister-Howells (ed.). Rutgers Turfgrass Proc. 23:144-191. Somerset, N.J. 13 Dec. 1991. Dept. of Plant Sci., Rutgers Univ. New Brunswick, N.J.

Ehrler, W.L., S.B. Idso, R.D. Jackson, and R.J Reginato. 1978. Wheat canopy temperature: relation to plant water potential. Agron. J. 70:251256.

Feldhake, C.M., R.E. Danielson, and J.D. Butler. 1983. Turfgrass evapotranspiration. I. Factors influencing rate in urban environments. Agron. J. 75:824-830.

Gunaskera, D. and G.A. Berkowitz. 1992. Evaluation of contrasting cellular-level acclimation responses to leaf water deficits in three wheat genotypes. Plant Sci. 86:1-12.

Howard, H.F. and T.L. Watschke. 1991. Variable high-temperature tolerance among Kentucky bluegrass cultivars. Agron. J. 83:689-693.

Idso, S.B., R.J. Reginato, D.C. Reicosky, and J.L. Hatfield. 1981. Determining soil-induced plant water potential depressions in alfalfa by means of infrared thermometry. Agron. J. 73:826-830.

Pier, P.A. and G.A. Berkowitz. 1987. Modulation of drought stress effects on photosynthesis by altered leaf $\mathrm{K}^{+1}$. Plant Physiol. 85:655-661.

Salaiz, T.A., R.C. Shearman, T.P. Riordan, and E.J. Kinbacher. 1991. Creeping bentgrass cultivar water use and rooting responses. Crop Sci. 31:1331-1334.

Schery, R.W. 1976. Lawn keeping. Prentice-Hall Englewood Cliffs, N.J.

Sen Gupta, A. and G.A. Berkowitz. 1987. Osmotic adjustment, symplast volume, and nonstomatally mediated drought stress inhibition of photosynthesis in wheat. Plant Physiol. 85:1040-1047.

Sharp, R.E. and J.S. Boyer. 1986. Photosynthesis at low water potentials in sunflower: Lack of photoinhibitory effects. Plant Physiol. 82:90 95.

Sifers, S.I. and J.B. Beard. 1993. Comparative interand intra-specific leaf firing resistance to supraoptimal air and soil temps in cool-season turfgrass genotypes, p. 621-628. In: R.N. Carrow, N.E. Christians, and R.C. Shearman (eds.). Intl. Turf. Soc. Res. J. Intertech Publishing Corp., Overland Park, Kan.

Smucker, A.J.M., S.L. McBurney, and A.K. Srivastava. 1982. Quantitative separation of roots from compacted soil profiles by the hydropneumatic elutriation system. Agron. J. 74:500-503.

Steel, R.G.D. and J.H. Torrie. 1980. Principles and procedures of statistics: A biometrical approach. McGraw Hill, New York.

Tanner, C.B. 1963. Plant temperatures. Agron. J. 55:210-211.

Throssell, C.S., R.N. Carrow, and G.A. Milliken. 1987. Canopy temperature based irrigation scheduling indices for Kentucky bluegrass turf. Crop Sci. 27:126-131.

Turner, N.C. 1981. Techniques and experimental approaches for the measurement of plant water status. Plant Soil 58:339-366.

Walker, G.K. and J.L. Hatfield. 1983. Stress measurement using foliage temperature. Agron. J. 75:623-629.

White, R.H., M.C. Engelke, S.J. Morton, and B.A. Ruemmele. 1992. Competitive turgor maintenance in tall fescue. Crop Sci. 32:251-256. 